\title{
Rasulullah Saw the Pioneer of Literacy in the Muslim Community of Mecca
}

\author{
Ari Fauzi Rahman \\ Universitas islam negeri Sunan Gunung Djati Bandung \\ Jl. A.H. Nasution No.105, Cipadung, Kec. Cibiru, Kota Bandung, Jawa Barat 40614 \\ AriFauzi72@gmail.com
}

\begin{abstract}
:
After the messenger of Allah (Rasulullah Saw) was sent, the first revelation that was revealed Qs. al-'Alaq 1-5 which was delivered by Gabriel or Jibril when Rasulullah was sleeping in Cave of Hira. But because of the fear of Rasulullah Saw, come down Qs. al-Muddatsir [74]: 1-2 with the order to wake up and give a warning to the people around you. However, the prophet found some obstacles, namely the condition of the Arabian people of Mecca at that time still adhering to paganism and polytheism as well as the Arab society that was less intellectual, as evidenced by the lack of the Arab Makkah community who could write and read. There were 17 men and 5 women who could write and read at the time. Seeing the condition of the Arabian community of Mecca who was ignorant, the Prophet Muhammad made his preaching secretly by inviting his wife, family, closest friends, and servants. Finally, the Prophet Muhammad received 38 people embraced Islam and made Darul Arqam as the center of scientific teachings of Islam for the first time. Darul Arqam is the house of a friend named Arqam ibn Arqam. The efforts of the Prophet to preach the true revelations and the desire to form a literary Arab society finally paid off. After the war, the Prophet Muhammad Saw captured 70 people, the aim of which was to find prisoners who could read and write to teach the Muslim community at that time. After Darul Arqam as the center of teaching of monotheism and accepting people who wished to convert to Islam, the Prophet developed a kuttab that had previously existed but was less interested. Kuttab was used as a place for teaching reading and writing for Muslim communities at that time. Thus there is a difference in the curriculum of the two educational institutions developed by Rasulullah Saw.
\end{abstract}

Keywords: Rasulullah, Literacy, Mecca

\section{A. INTRODUCTION}

The city of Mecca is a city whose specialities are planned before the Prophet Adam descends to the earth, it is based on Allah Almighty instructing angels to make an area of thawaf on earth as in Arsy and Baitul Makmur. According to the mujahid the city of Mecca was determined as the axis of 'Arsy and Baitul Makmur two thousand years before the Prophet Adam As down to earth. Thus the city of Mecca is the first place of worship that is directly connected vertically with the Arsy without any obstacles. ${ }^{1}$

According to Imam Al-Mawardi, based on sources of transmission, the origin of the word Mecca in the Qur'an is "Bakkah" (the cry of the Prophet Adam) contained in Qs.

1 Ajid Thohir, Sirah Nabawiyah (Nabi Muhammad Saw dalam Kajian Ilmu SosialHumaniora) (Badung: Marja, 2014), 200.
Al-Imran [3]: 96. Then it becomes the word Mecca which means the place of crying or the repentance of the children of Adam's descendants towards the sacred spiritual soul.

In the beginning, the religion of the Arab community, especially the city of Mecca, was largely inherited from its predecessors, hanif Ibrahim As. But hanif religion changed after the death of Prophet Ibrahim As by a leader Bani Khuza'ah who was known as a wise and generous person so respected by the Arab community around Mecca named Amr ibn Luhay ibn Qam'ah.

As Ibn Ishaq narrated from Muhammad ibn Ibrahim ibn at-Tamimi, Salih as-Saman told him that he had once said Abu Hurairah: I once heard the Prophet said to Aktham ibn jun al-Khuza'I, "O Aktam, I have 
seen Amr ibn Luhay ibn Qama'ah pulled his intestines into hell. I see no one like his face except you. "Then Aktsam said, "Will the likeness of the image endanger me, Rasulullah?", Rasulullah Saw replied, "No, because you are a believer, while he is an infidel. Indeed, he was the person who first changed the religion of Ismail As. He made statues, cut off the ears of the mother to offer them to the thaguts, slaughtered animals to their gods, allowed the camels to worship and ordered not to ride certain camels, because of faith in idols."

Amr ibn Luhay had adopted the idolatry of the residents of Sham, especially the followers of Sham ibn Noah who had idols such as Wud, Suwa', Yaguhts, Ya'uq and Nasr, Manat, Latta and Uzza. ${ }^{2}$ Even the people of the city of Mecca began displaying idols which are symbols of their tribe around the Ka'bah. This has spawned the seeds of division behind his superstition because of the symbols they have each. ${ }^{3}$ But not all Arabs follow Amr ibn Luhay to worship idols, as the jurhum tribe opposed to that teachings because they deviated from the teachings of Abraham. Opposition to the tribe of the deceased was carried out in the form of poems that were chanted as a condemnation of Amr ibn Luhay. ${ }^{3}$

Drastic changes to the teachings of Prophet Jesus son of Mary took place. After the death of Prophet Isa As. His loyal followers became paganists accompanied by polytheism which was transformed into the essence of God into the Trinity. Since the age of the Trinity religion entered the $6^{\text {th }}$-century teachings of the Prophet Isa As. It starts out and turns into the seeds of evil. ${ }^{4}$

The light of change seems to be beginning to appear, namely at the birth of the Prophet Muhammad Saw in the city of Mecca from Abdullah ibn Abdul Muthalib and Aminah's family as Hasyim's extended

${ }^{2}$ Moenawar Chalil, Kelengkapan Tarikh Nabi Muhammad $S A W$, jilid 1 (Jakarta: Gema Insani, 2001), 24.

${ }^{3}$ M. Quraish Shihab, Membaca Sirah Nabi Muhammad Saw dalam Sorotan Alquran dan Hadits Shahih (Jakarta: Lentera Hati, 2011), 86. family in 571 AD. The light of the birth of the Prophet Muhammad Saw marked by the collapse of idolatrous religious facilities, such as the destruction of ten balconies of the Kisra Palace, extinguishing of the fire worshiped by the majusi, until the collapse of several churches around Buhairah and his birth were compared by the scholars in Syria. ${ }^{5}$

After the sending of the Prophet Muhammad Saw received a revelation he was obliged to deliver the revelation to the local community. But the Prophet Muhammad Saw had many obstacles to convey the revelation to the local community, namely the Mecca community. Some of these obstacles are, among others, the condition of the Mecca community which still adheres to paganism (belief in worshiping idols) and polytheism (worshiping more than one God) which is difficult to change because it has been done for a long time. ${ }^{6}$

In addition to the conditions of the Mecca society, which at that time was paganism and polytheism, the Mecca community was also blind in terms of reading and writing. This is what drives the Meccan community at that time called the jahiliyah community filled with darkness and ignorance.

Based on the explanation above, this study will discuss how the Prophet's efforts to form a literacy Muslim community?

The method used in this article is a literature study, as research in the science of hadith has a hadith critique method consisting of religious disciplines in it or can be called Musthalah al-hadith. So that this research is more focused on the literature study with its primary source, the book of Sunan Tirmidhi and its secondary sources of data that can help this article.

\footnotetext{
${ }^{4}$ Muhammad al Ghazali, Sejarah Perjalanan Hidup Muhammad(Yogyakarta: Mitra Pustaka, 2008), 3.

${ }^{5}$ Thohir, Sirah Nabawiyah (Nabi Muhammad Saw dalam Kajian Ilmu Sosial-Humaniora), 215.

6 al Ghazali, Sejarah Perjalanan Hidup Muhammad, 4.
} 


$$
\text { أبشريا محمد!!! الانا جبريل وانت رسول الله إلى هذه }
$$

\section{B. RESULT AND DISCUSSION}

\section{1) Rasulullah SAW Delivered the Revelation}

As in the introduction, it was stated that Rasulullah had several obstacles to disseminate the revelations that were entrusted to him. First, because Arab society in general at the time was a society that embraced the teachings of paganism and polytheism. Second, the habits of Arab society, in general, have a greedy character so that war often occurs. Third, in general, the Arab community before Islam came illiterate and could not write (Ummi). ${ }^{7}$

In the conditions of the ignorant Arab community, the Prophet Muhammad Saw was more pleased to worship in the Cave of Hira. To calm his mind, get the truth and cleanse the heart. The custom of the Prophet Muhammad Saw to leave or be alone in a place far from the crowds was also often carried out by Arabs during the ignorance era, this has become the custom of the Arabs. The Arabs named the custom with tahannuf (holding firm to the religion that was embraced) or tahannuts (worshiping God). ${ }^{8}$

After repeatedly praying at Gua Hira, one night when Prophet Muhammad Saw slept, he dreamed of seeing bright light like a bright light in the morning. This added to his passion for seeking truth in the midst of the life of the ignorant Arab community.

The age of the Prophet Muhammad Saw at that time entered forty years old, in him began to feel concerned that he would be tempted by a genie. One night when the Prophet Muhammad Saw was sleeping in Gua Hira, suddenly he arrives a man who had never been known before. Instantly the person said in a loud voice to him:

\footnotetext{
${ }^{7}$ Agus Rifai, Perpustakaan Islam (Konsep, Sejarah dan Kontribusinya dalam Membangun Peradaban Islam Masa Klasik) (Jakarta: Rajagrafindo Persada, 2013), 25.
}

"Be happy O Muhammad, I am Gabriel and you are the messanger of Allah to these people (Ummah)"

As Imam Al-Bukhari narrated from Aisyah Ra who told of the first revelation he said:

Then the Angel Gabriel revealed a piece of paper, then instructed him to read the writing while saying, "Read it!" He replied, "I Can't read". The Prophet said further: Angel Gabriel then approached and hugged me so that I felt very weak, then I was released. He said again, "Read it!" But still, I replied, "I can't read", He approached me again and held me close so that I felt completely helpless, then I was released. He said again, "Read it!" I replied, "I can't read". 9

For the third time, he approached me and hugged me until I felt weak, then I was released. Next, he said, "Read in the name of your God who created. Creating humans from a blood clot. Read and your Lord the Gracious, who has taught (man) by means of a pen. He taught humans what he did not know."

After that Rasulullah returned with these verses in a state of shivering until he entered the house to meet the khadijah and said "Envelop me! Envelop me!" then he was enveloped so that his fear disappeared. Then he said to the khadijah, "O Khadijah, do you know what happened to me?" then he told about the incident he had just experienced. Then he said, "I am really worried about myself (from the interference of the genie)." But khadijah said, "No, calm your heart, for Allah's sake, Allah will not make you disappointed. Because you are a person who likes to connect family cords, always helping poor people, respecting guests and defending people who stand above the truth."

\footnotetext{
8 Chalil, Kelengkapan Tarikh Nabi Muhammad $S A W$, jilid 1, 106

${ }^{9}$ Muhammad Husein Haekal, Sejarah Hidup Muhammad (Jakarta: Pustaka Jaya, 1980), 169. Terj Ali Audah.
} 
Then Khadijah brought Rasulullah Saw away to meet Waraqah ibn Naufal, one of the children of Siti Khadijah's uncle. In the time of his ignorance of embracing Christianity, he had written parts of the Gospel in Hebrew. He was an old person and could not see. Khadijah said to him, "O my uncle's son, listen to what your brother's son (ie Muhammad Saw) said", Waraqah asked Muhammad Saw, "O my brother's son, what is wrong with you?" then Rasulullah told what he had experienced, then Waraqah said, "That is the Angel that was revealed to Musa As, I dreamed of returning to my youth, I dreamed that I would still be alive when you were cast out by your people". Then Rasulullah Saw asked, "Will they send me away?", Replied Waraqah, "Yes, No one comes to bring like what you bring except to be hostile, if I still live and experience the day you face, I will definitely help you". Shortly afterward Waraqah died. (This hadith issued in shahih Bukhori, Muslim dan az-Zuhri). ${ }^{10}$

Thus the first revelation received by the Prophet was Qs. al-Alaq [96]: 1-5. In the first revelation he was not ordered by Allah to give a warning and invite humanity to return to the right path. His status was still a Prophet at the time of the reception of the first revelation, only when his revelation did his second status become a Prophet and Rasulullah or the messenger of Allah. ${ }^{11}$

As al-Baihaqi related a hadith from Jabir ibn Abdillah, he said: I heard Rasulullah Saw talking about the cessation of revelation. $\mathrm{He}$ said to me, "When I was walking, I suddenly heard a voice from the sky. When I lifted my head, it turned out that the angel came to me at the Cave of Hira, "I saw he was sitting in the chair between sky and earth. I immediately went home to meet my wife and

10 Sayyid Quthb, Tafsir Fi Zhilalil Qur'an (Dibawah Naungan Alquran) (Depok: Gema Insani Press, t.t), 201.

11 M. Quraish Shihab, Membumikan AlQur'an (Fungsi dan Peran Wahyu dalam Kehidupan Masyarakat) (Badung: Mizan, 1996), 21.

12 Thohir, Sirah Nabawiyah (Nabi Muhammad Saw dalam Kajian Ilmu SosialHumaniora), 133.
I told her, "Envelope me, envelope me, envelope me!." 12

Then Allah said in Qs. alMudatsir [74] : 1-2, You, wrapped in your cloak, Arise and give warning.

According to M. Quraish Shihab from the incident of the second revelation received by the Prophet Muhammad Saw there were three contents. First, education for the Rasulullah Saw in forming his leadership: You [Prophet], enfolded in your cloak!. Stay up throughout the night, all but a small part of it, half, or a little less, or a little more; recite the Qur'an slowly and distinctly. (Qs. alMuzammil [73] : 1-4). This commandment is due to the fact that we will bring down to you a very heavy revelation (Qs. al-Muzammil [73]: 5). Second, basic knowledge about the nature and nature of Allah, and third, information about the basics of Islamic morality, as well as general denial about the life view of the ignorant people at that time. ${ }^{13}$

First of all the Prophet Muhammad invited Khadijah r.a to convert to Islam then his cousin (Muhammad) namely Ali r.a at that time Ali was 10 years old. Then Zaid ibn Harithah was his former servant (Muhammad), then Abu Bakar as-Siddiq r.a, then Bilal ibn Rabbah a slave servant. ${ }^{14}$ Gradually the invitation began to expand but was still limited among the Quraysh tribes such as, Ustman ibn Affan r.a, Zubair ibn Awan r.a, Sa'ad ibn Abi Waqas r.a, Abdurrahman ibn Auf r.a, Thalhah ibn Ubaydillah r.a, Abu Ubaydillah ibn Jahrah r.a, Arqam ibn Arqam r.a, Fatimah ibnti Khattab r.a, Said ibn Zaid r.a and a number of other people they were called assabiquna alAwwalun. ${ }^{15}$

13 Quraish Shihab, Membumikan Al-Qur'an (Fungsi dan Peran Wahyu dalam Kehidupan Masyarakat), 22.

${ }^{14}$ Mustafa as-Syibaie, Sirah Nabi Muhammad S.A.W Pengajaran dan Pedoman (Siri Tarbiyah: Konsis Media, t.t), 23.

15 Iskandar dan Najmuddin, "Pola Pendidikan Islam Pada Periode Rasulullah di Mekkah dan Madinah," Lentera 13, no. 3 (2013): 68. 


\section{2) The Efforts of Rasulullah to Form a Literacy in Mecca Society}

Rasulullah Saw was an ummi (unable to read) it was proven during the process of the first revelation which was ordered by the angel Gabriel to read the Mushaf given to Rasulullah, then he replied "What should I read?" it was repeated three times. This was confirmed also in several verses of the Qur'an, including:

who follow the Messenger- the unlettereda prophet they find described in the Torah that is with them, and in the Gospelwho commands them to do right and forbids them to do wrong, who makes good things lawful to them and bad things unlawful, and relieves them of their burdens, and the iron collars that were on them. So it is those who believe him, honour and help him, and who follow the light which has been sent down with him, who will succeed.' (Qs. al-'Araf [7]: 157)

Say [Muhammad], 'People, I am the Messenger of God to you all, from Him who has control over the heavens and the earth. There is no God but Him; He gives life and death, so believe in God and His Messenger, the unlettered Prophet who believes in God and His words, and follow him so that you may find guidance.' (Qs. al-'Araf [7]: 158)

You never recited any Scripture before We revealed this one to you; you never wrote one down with your hand. If you had done so, those who follow falsehood might have had cause to doubt. (Qs. al-Ankabut [29]: 48)

Also in a hadith narrated from Ibn Umar, the Prophet Muhammad Saw said, "Kita adalah umat yang ummi, tidak menulis dan tidak berhitung" (Shahih Bukhari, Juz III,. 27-28). ${ }^{16}$

These arguments reinforce the explanation that the Qur'an is not the word of the Prophet Muhammad as the criticism made by some Orientalists. Clear in Qs. Al-Ankabut verse 48 is mentioned if the Prophet Muhammad Saw was not an ummi, then the ignorant community at that time would

16 Thohir, Sirah Nabawiyah (Nabi Muhammad Saw dalam Kajian Ilmu SosialHumaniora), 156. certainly deny the revelation received by Rasulullah Saw. So the statement of some Orientalists about the Qur'an is written by the Prophet Muhammad Saw can be broken. ${ }^{17}$

Ibn Katsir interprets Qs al-Ankabut verse 48, You never recited any Scripture before We revealed this one to you; you never wrote one down with your hand. If you had done so, those who follow falsehood might have had cause to doubt, the meaning you (Muhammad) have lived in the midst of your people before you came to bring the Qur'an, while you cannot read or cannot write. Even everyone from your people and besides they know that you are an illiterate person who cannot read and write. The character ummi of Rasulullah Saw was also listed in the previous books as Allah said, those who follow the Apostle, the uninstructed prophet, whose mention they find written with them in the Torah and the Evangel, who bids them to do what is right and forbids them from what is wrong, makes lawful to them all the good things and forbids them from all vicious things, and relieves them of their burdens and the shackles that were upon them - those who believe in him, honour him, and help him and follow the light that has been sent down with him, ${ }^{1}$ they are the felicitous.' This also strengthens, too (if you can read and write) surely you will feel the people who deny you. This means that if Muhammad could write for sure some fools would hesitate, then would say "You only know this from the previous books taken from the prophets". ${ }^{18}$

The condition of Rasulullah Saw forever could not write either one line. It was also found several letters of Rasulullah Saw to the rulers to several lands written by the Companions. Simply put, the Prophet Muhammad Saw with his ummi was found in the books of other prophets.

The second revelation that descended on the Prophet was the order to broadcast the revelations he had received, Qs al-Mudatsir [74] : 1-2, You, wrapped in your cloak, arise and give warning!

${ }^{17}$ Quthb, Tafsir Fi Zhilalil Qur'an (Dibawah Naungan Alquran), 305.

18 Abu Fida Isma'il Ibnu Katsir, Tafsir Ibn Katsir (Bandung: Sinar Baru Algesindo, 2000), 343. 
Wahbah Al-Zuhaili interprets the word (قم فأنذر) is to wake up and give a frightening warning to the people of Mecca and ask them that they will be overtaken if they do not embrace Islam. ${ }^{19}$

After mentioning several families and friends who started embracing Islam, Rasulullah Saw held an educational institution in the early days of Arqam ibn Arqam's house known as Darul al-Arqam. Teaching in the early period was about the basics of Islamic teachings and conveying the revelations of the Qur'an to friends. Teaching at Arqam's house was carried out clandestinely. After Umar ibn Khattab embraced Islam the da'wah center was transferred to the house of Rasulullah saw.

Rasulullah Saw used Darul Arqam in addition to the first educational institution as well as a meeting place with friends. The number of friends at that time was still relatively small, 38 of which were made up of the nobility of the Quraysh, the merchants, and the servants. Rasulullah Saw also taught the Companions to memorize, appreciate and practice the verses received by Rasulullah Saw. Darul Arqam also acts as a place to accept people who want to convert to Islam and there also Rasulullah Saw worshiped with his friends. ${ }^{20}$

Besides Darul Arqam, the formal educational institution that was made as an effort by the Prophet Muhammad to form a literacy Meccan society was the Kuttab. Although the Kuttab already existed before the Prophet was sent, it was less desirable because their culture was trading. Learning the Kuttab is different from the Arqam house, namely learning Kuttab emphasizes more education for writing and reading.

The Quraysh tribes at that time were able to write very few, there are 17 men and 5 women. Among the men who could write

19 Wahbah al-Zuhayli, al-Tafsir al-Munir Fi al-Aqidah al-Syar'iyah al-Manhaj (Beirut: Darul Fikr, t.t), 220 .

${ }^{20}$ Mahmud Yunus, Sejarah Pendidikan Islam (Jakarta: Hidakarya Agung, 1992), 6.

${ }^{21}$ Gusti Irahman Husin, "Pemikiran Tentang Sistem dan Kelembagaan Pendidikan Islam di Masa Rasulullah Pada Periode Mekkah dan Periode were 1. Umar ibn khattab, 2. Ali ibn Abi Thalib, 3. Usman Ibn Affan, 4. Abu Ubaidah Ibn Jarrah, 5. Thalhah, 6. Yazid Ibn Abu Sofyan, 7. Abu Huzaifah Ibn Utbah, 8. Hatib Ibn Jarrah, 9. Abu Salamah Abd al-Asad alMakhzumi, 10. Aban Ibn Sa'ad, 11. Huwaitib Ibn Abd al-Uzza, 12. Abu Sufyan Ibn Harb, 13. Mu'awiyah Ibn Abu Sufyan, 14. Juhaini Ibn Shalt.

The five women were interviewed, 1 . Hafsah, 2. Ummi Kulsum Binti Uqbah, 3. Aisyah Binti Sa'ad, 4. Al-Sifa binti Abdullah al-Adawiyah, and 5. Karimah binti al-Miqdad. As for Siti Aisyah and Ummi Salamah, they could only read but could not write. ${ }^{21}$

The Kuttab was more focused after Rasulullah Saw moved to Medina because at the time in Medina the people who converted to Islam were mostly weak and illiterate citizens. Before migrating to Medina, the Rasulullah Saw once employed dhimmis to teach reading and writing to the Muslim community in Mecca. ${ }^{22}$

This is a form of the seriousness of the Rasulullah Saw to form a literacy Muslim community. Apart from employing the Mecca dzimmi, the people when Rasulullah Saw moved to Medina holding 70 postwar war prisoners Badar. By giving a choice: 1 . If the prisoner can read and write, he will be given an offer to teach the Muslim community 10 people if they don't want to enter the prison. 2. If the prisoner cannot read and write, they will enter the prison for several years. ${ }^{23}$

The educational process before Rasulullah Saw was something natural that had not taken place formally as was done by Rasulullah Saw when establishing a formal educational institution. When there are people who cannot read to meet people who can read and want to learn to read to them, there is a

Madinah," Jurnal Ilmiah Al Qalam 11, no. 24 (2017): 78.

22 Ahmad Syalibi, Sejarah Pendidikan Islam (Jakarta: Bulan Bintang, 1973), 34.

23 Ubaidillah, Pengelolaan Lembaga Pendidikan Pada Masa Rasulullah Saw (IAIN Jember: Al-Ittihad, tt), 13. 
learning process to read. This can be done anywhere and anytime. ${ }^{24}$

\section{CONCLUSION}

Thus Rasulullah Saw was a pioneer to form an illiterate Muslim community. As the first revelation revealed to him was the command "read", the order was repeated three times. This can be taken from the wisdom that Allah emphasizes to humans to "read" after that being recited from the knowledge that is read all comes from Allah.

Likewise, Rasulullah Saw strongly emphasized to his people to be able to read and write, as evidenced by the two institutions during the Mecca period namely Darul Arqam and the Kuttab. Although in it there is a different curriculum, the attention of Rasulullah Saw to his people to be intelligent people.

Rasulullah saw made Darul Arqam as the first center for the teaching of monotheism (Tauhidullah) and the preaching of Islam and the first place to accept people who wished to convert to Islam. Different from the Kuttab, which was developed by Rasulullah Saw as a center for studying reading and writing for illiterate Muslims.

\section{BIBLIOGRAFI}

Abu Fida Isma'il Ibnu Katsir. Tafsir Ibn Katsir. Bandung: Sinar Baru Algesindo, 2000.

Chalil, Moenawar. Kelengkapan Tarikh Nabi Muhammad SAW, jilid 1. Jakarta: Gema Insani, 2001.

Darajat, Zakiyah. Ilmu Pendidikan Islam. Jakarta: Bulan Bintang, 1996.

Ghazali, Muhammad al. Sejarah Perjalanan Hidup Muhammad. Yogyakarta: Mitra Pustaka, 2008.

Husein Haekal, Muhammad. Sejarah Hidup Muhammad. Jakarta: Pustaka Jaya, 1980.

Irahman Husin, Gusti. "Pemikiran Tentang Sistem dan Kelembagaan Pendidikan Islam di Masa Rasulullah Pada Periode

${ }^{24}$ Zakiyah Darajat, Ilmu Pendidikan Islam (Jakarta: Bulan Bintang, 1996), 21.
Mekkah dan Periode Madinah.” Jurnal Ilmiah Al Qalam 11, no. 24 (2017).

Iskandar dan Najmuddin. "Pola Pendidikan Islam Pada Periode Rasulullah di Mekkah dan Madinah." Lentera 13, no. 3 (2013): 68.

Quraish Shihab, M. Membaca Sirah Nabi Muhammad Saw dalam Sorotan Alquran dan Hadits Shahih. Jakarta: Lentera Hati, 2011.

_. Membumikan Al-Qur'an (Fungsi dan Peran Wahyu dalam Kehidupan Masyarakat). Badung: Mizan, 1996.

Quthb, Sayyid. Tafsir Fi Zhilalil Qur'an (Dibawah Naungan Alquran). Depok: Gema Insani Press, t.t.

Rifai, Agus. Perpustakaan Islam (Konsep, Sejarah dan Kontribusinya dalam Membangun Peradaban Islam Masa Klasik). Jakarta: Rajagrafindo Persada, 2013.

Syalibi, Ahmad. Sejarah Pendidikan Islam. Jakarta: Bulan Bintang, 1973.

Syibaie, Mustafa as-. Sirah Nabi Muhammad S.A.W Pengajaran dan Pedoman. Siri Tarbiyah: Konsis Media, t.t.

Thohir, Ajid. Sirah Nabawiyah (Nabi Muhammad Saw dalam Kajian Ilmu Sosial-Humaniora). Badung: Marja, 2014

Ubaidillah. Pengelolaan Lembaga Pendidikan Pada Masa Rasulullah Saw. IAIN Jember: Al-Ittihad, tt.

Yunus, Mahmud. Sejarah Pendidikan Islam. Jakarta: Hidakarya Agung, 1992.

Zuhayli, Wahbah al-. al-Tafsir al-Munir Fi alAqidah al-Syar'iyah al-Manhaj. Beriut: Darul Fikr, t.t.

Suryadilaga, Muhammad Alfatih, "Kajian Hadis Di Era Global”, Esensia, Vol. 15, No. 2, September 2014. 
